\title{
Leucascandrolide A: A second generation formal synthesis
}

David R. Williams, * Samarjit Patnaik, and Scott V. Plummer

\author{
Department of Chemistry \\ Indiana University
}

Bloomington, Indiana 47405-7102

Supporting information

Experimental procedures and spectral data for compounds

$\mathbf{2}, \mathbf{4}, \mathbf{7}-9, \mathbf{1 2}, \mathbf{1 7}-\mathbf{2 3}$, and the proton NMR spectrum of macrolide 2 are provided. 


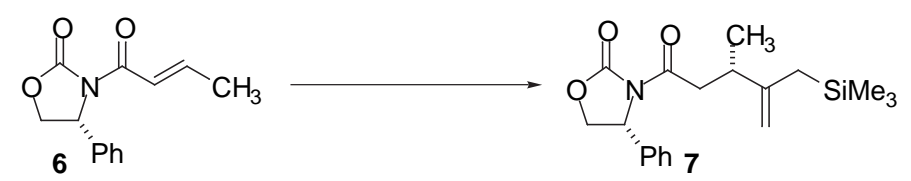

Allysilane 7: A two-necked $50 \mathrm{~mL}$ round bottomed flask, fitted with a water condenser and a septum, was charged with a stirrer bar and magnesium turnings $(2.70 \mathrm{~g}, 111 \mathrm{mmol}$, freshly ground with mortar and pestle) and the system was flame dried with vigorous stirring. After cooling to room temperature, THF $(25 \mathrm{~mL})$ was added followed by 1,2dibromoethane $(50 \mu \mathrm{L})$. Gentle reflux was observed after 5 min of stirring, after which $0.2 \mathrm{~mL}$ of neat 2-(bromo)-allyltrimethylsilane was added. The mixture was stirred approximately 5 min till the Grignard reaction was initiated at which time the rest of the 2(bromoallyl)-trimethylsilane $(4.78 \mathrm{~mL}, 27.8 \mathrm{mmol})$ was added dropwise over $30 \mathrm{~min}$ maintaining a steady reflux. The greenish Grignard solution (Note: if precipitation occurs it can be redissolved by heating at $\sim 50^{\circ} \mathrm{C}$ ) was then added via cannula (or syringe) to a suspension of $\mathrm{CuBr} \bullet \mathrm{DMS}(5.71 \mathrm{~g}, 27.8 \mathrm{mmol})$ in THF $(14 \mathrm{~mL})$ at $-40{ }^{\circ} \mathrm{C}$. The suspension was stirred at $-40{ }^{\circ} \mathrm{C}$ for $30 \mathrm{~min}$, cooled to $-78^{\circ} \mathrm{C}$ and a solution of $N$-enoyl1,3-oxazolidin-2-one 6 (3.21 g, $13.9 \mathrm{mmol})$ in THF (14 mL) was added dropwise over a period of $1 \mathrm{~h}$. The resultant black suspension was stirred at $-78^{\circ} \mathrm{C}$ for $3 \mathrm{~h}$ and then stirred at $-20^{\circ} \mathrm{C}$ for $10 \mathrm{~h}$. The reaction was quenched at $-20^{\circ} \mathrm{C}$ with $5 \mathrm{~mL}$ of saturated aqueous $\mathrm{NH}_{4} \mathrm{Cl}$, diluted with $\mathrm{Et}_{2} \mathrm{O}(25 \mathrm{~mL})$, warmed to room temperature and then filtered through a pad of Celite ${ }^{\circledR}$. The filtrate was washed with saturated aqueous $\mathrm{NH}_{4} \mathrm{Cl}(50 \mathrm{~mL})$ and the layers separated. The aqueous layer was extracted with $\mathrm{Et}_{2} \mathrm{O}(50 \mathrm{~mL})$, the organic layers were combined, dried $\left(\mathrm{MgSO}_{4}\right)$, filtered, and concentrated in vacuo. The crude residue was purified by flash silica gel chromatography (10\% EtOAc in hexanes) to afford $3.53 \mathrm{~g}$ (74\%, dr $>20: 1)$ of allylsilane 7 as a colorless oil: $\mathrm{R}_{f}=0.45$ in $25 \%$ EtOAc/hexanes; $[\alpha]_{\mathrm{D}}^{20}-55.2$ (c 27.0, $\mathrm{CH}_{2} \mathrm{Cl}_{2}$ ); IR (neat) 3097, 3027, 2958, 2897, 1787, 1760, 1710, 1626, 1453, $1238 \mathrm{~cm}^{-1} ;{ }^{1} \mathrm{H}$ NMR $\left(400 \mathrm{MHz}, \mathrm{CDCl}_{3}\right) \delta 7.40-7.26(\mathrm{~m}, 5 \mathrm{H}), 5.43(\mathrm{dd}, J=$ $3.6,8.8 \mathrm{~Hz}, 1 \mathrm{H}), 4.68(\mathrm{dd}, J=8.8,8.8 \mathrm{~Hz}, 1 \mathrm{H}), 4.63(\mathrm{~d}, J=0.9 \mathrm{~Hz}, 1 \mathrm{H}), 4.52(\mathrm{~d}, J=$ 
$0.9 \mathrm{~Hz}, 1 \mathrm{H}), 4.27(\mathrm{dd}, J=3.6,8.8 \mathrm{~Hz}, 1 \mathrm{H}), 3.22(\mathrm{dd}, J=5.6,16.4 \mathrm{~Hz}, 1 \mathrm{H}), 2.81(\mathrm{dd}$, $J=8.8,16.4 \mathrm{~Hz}, 1 \mathrm{H}), 2.50(\mathrm{~m}, 1 \mathrm{H}), 1.50(\mathrm{~s}, 2 \mathrm{H}), 1.00(\mathrm{~d}, J=6.8 \mathrm{~Hz}, 3 \mathrm{H}), 0.03(\mathrm{~s}$, $9 \mathrm{H}) ;{ }^{13} \mathrm{C} \mathrm{NMR}\left(101 \mathrm{MHz}, \mathrm{CDCl}_{3}\right) \delta 171.7,153.6,151.0,139.1,129.0,128.5,125.9$, 106.0, 69.8, 57.5, 41.3, 36.6, 25.6, 19.2, -1.4; HRMS m/e calcd for $\mathrm{C}_{19} \mathrm{H}_{27} \mathrm{NO}_{3} \mathrm{Si}$ $(\mathrm{M})^{+}$345.1760, found 345.1758.

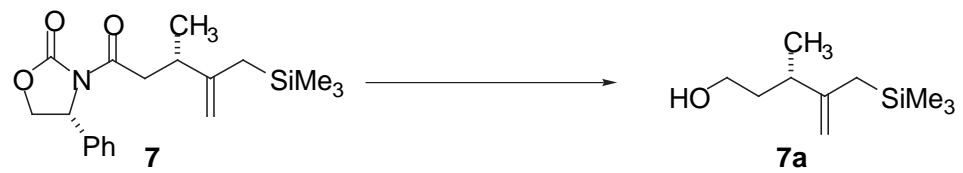

Alcohol 7a: Methanol $(240 \mu \mathrm{L}, 5.93 \mathrm{mmol})$, followed by solid $\mathrm{LiBH}_{4}(130 \mathrm{mg}, 5.97$ mmol) was added to a solution of oxazolidinone $7(510 \mathrm{mg}, 1.48 \mathrm{mmol})$ in $\mathrm{Et}_{2} \mathrm{O}(10 \mathrm{~mL})$ at $0{ }^{\circ} \mathrm{C}$. The reaction was stirred at $0{ }^{\circ} \mathrm{C}$ for $2 \mathrm{~h}$ and then quenched carefully with saturated aqueous $\mathrm{NaHCO}_{3}(10 \mathrm{~mL})$. The layers were separated, the aqueous layer extracted with $\mathrm{Et}_{2} \mathrm{O}(20 \mathrm{~mL})$. The organic layers were combined, dried $\left(\mathrm{MgSO}_{4}\right)$, filtered, and concentrated in vacuo. The crude residue was purified by flash silica gel chromatography (10\% EtOAc in hexanes) to afford $222 \mathrm{mg}(81 \%)$ of alcohol $7 \mathbf{a}$ as a colorless oil: $\mathrm{R}_{f}=0.17$ in $10 \%$ EtOAc/hexanes, $[\alpha]_{\mathrm{D}}^{27}+18.9$ (c 4.98, Et $2 \mathrm{O}$ ); IR (neat) 3328, 3080, 2958, 1631, $1248 \mathrm{~cm}^{-1} ;{ }^{1} \mathrm{H}$ NMR $\left(400 \mathrm{MHz}, \mathrm{CDCl}_{3}\right) \delta 4.67(\mathrm{~s}, 1 \mathrm{H}), 4.58(\mathrm{~s}, 1 \mathrm{H}), 3.66(\mathrm{~m}, 2 \mathrm{H})$, $2.12(\mathrm{ddt}, J=6.8,6.8,6.8 \mathrm{~Hz}, 1 \mathrm{H}), 1.74(\mathrm{dddd}, J=13.6,6.8,6.8,6.8 \mathrm{~Hz}, 1 \mathrm{H}), 1.57$ (dddd, $J=13.6,6.8,6.8,6.8 \mathrm{~Hz}, 1 \mathrm{H}), 1.53(\mathrm{~s}, 2 \mathrm{H}), 1.28$ (t, $J=5.6 \mathrm{~Hz}, 1 \mathrm{H}), 1.04$ (d, $J$ $=6.8 \mathrm{~Hz}, 3 \mathrm{H}), 0.03(\mathrm{~s}, 9 \mathrm{H}) ;{ }^{13} \mathrm{C} \mathrm{NMR}\left(101 \mathrm{MHz}, \mathrm{CDCl}_{3}\right) \delta$ 152.4, 105.9, 61.4, 38.4, 37.6, 25.3, 19.7, -1.2; HRMS m/e calcd for $\mathrm{C}_{10} \mathrm{H}_{22} \mathrm{OSi}(\mathrm{M})^{+} 186.1440$ found 186.1438.

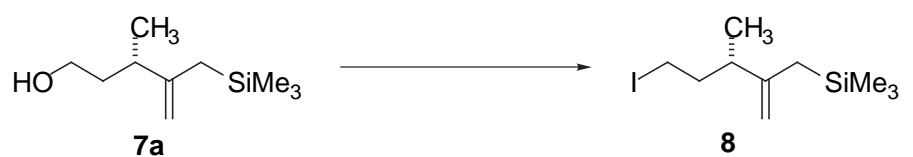

Iodide 8: Dicyclohexylcabodiimide•iodomethane complex (11.0 g, $31.6 \mathrm{mmol})$ was added to a solution of alcohol 7a $(1.36 \mathrm{~g}, 7.31 \mathrm{mmol})$ in THF $(100 \mathrm{~mL})$ at room temperature. The reaction was stirred at $40^{\circ} \mathrm{C}$ for $12 \mathrm{~h}$, concentrated in vacuo and purified 
by flash silica gel chromatography (100\% hexanes) to afford $1.76 \mathrm{~g}(81 \%)$ of iodide $\mathbf{8}$ : $\mathrm{R}_{f}$ $=0.86$ in $10 \%$ EtOAc/hexanes; $[\alpha]_{\mathrm{D}}^{21}+11.5$ (c 11.5, $\mathrm{CH}_{2} \mathrm{Cl}_{2}$ ); IR (neat) 3079, 2958, 1630, $1248 \mathrm{~cm}^{-1} ;{ }^{1} \mathrm{H}$ NMR (400 $\left.\mathrm{MHz} \mathrm{CDCl}_{3}\right) \delta 4.64(\mathrm{~s}, 1 \mathrm{H}), 4.60(\mathrm{~s}, 1 \mathrm{H}), 3.17(\mathrm{~m}$, 2H), 2.07 (ddt, $J=6.8,6.8,6.8 \mathrm{~Hz}, 1 \mathrm{H}), 2.00$ (dddd, $J=14.0,7.0,7.0,7.0 \mathrm{~Hz}, 1 \mathrm{H})$, $1.78(\mathrm{dddd}, J=14.0,7.0,7.0,7.0 \mathrm{~Hz}, 1 \mathrm{H}), 1.50(\mathrm{~s}, 2 \mathrm{H}), 1.01(\mathrm{~d}, J=6.8 \mathrm{~Hz}, 3 \mathrm{H})$, $0.03(\mathrm{~s}, 9 \mathrm{H}) ;{ }^{13} \mathrm{C}$ NMR (101 MHz, $\left.\mathrm{CDCl}_{3}\right) \delta 150.7,106.6,41.5,39.7,25.2,18.9,5.3$, -1.1; HRMS m/e calcd for $\mathrm{C}_{10} \mathrm{H}_{21} \mathrm{ISi}(\mathrm{M})^{+} 296.0457$, found 296.0449.

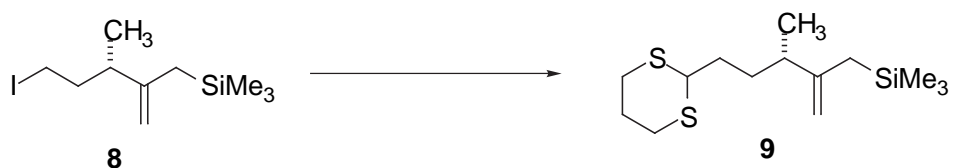

Dithiane 9: ${ }^{n}$ Butyllithium (2.5 $\mathrm{M}$ in hexanes, $\left.4.09 \mathrm{~mL}, 10.2 \mathrm{mmol}\right)$ was added dropwise to a solution of 1,3 -dithiane $(1.20 \mathrm{~g}, 9.98 \mathrm{mmol})$ in $\mathrm{THF}(15.8 \mathrm{~mL})$ at $-30{ }^{\circ} \mathrm{C}$. The mixture was stirred at a temperature between $-20{ }^{\circ} \mathrm{C}$ to $-30{ }^{\circ} \mathrm{C}$ for $1.5 \mathrm{~h}$ and maintained at that temperature to afford a $0.5 \mathrm{M}$ solution of 2-lithio-1,3-dithiane in THF. A solution of iodide 8 (1.52 g, $5.13 \mathrm{mmol})$ in THF $(6.0 \mathrm{~mL})$ was added to 2-lithio-1,3-dithiane $(0.5 \mathrm{M}$ in THF, $14 \mathrm{~mL}, 7.0 \mathrm{mmol}$ ) at $-78^{\circ} \mathrm{C}$ via cannula. The mixture was gradually warmed to 0 ${ }^{\circ} \mathrm{C}$, stirred for $2 \mathrm{~h}$ at $0{ }^{\circ} \mathrm{C}$ and then quenched by dropwise addition of saturated aqueous $\mathrm{NaHCO}_{3}$. The reaction mixture was diluted with pentane $(30 \mathrm{~mL})$, washed with water (30 $\mathrm{mL})$ and $7 \%$ aqueous $\mathrm{KOH}(30 \mathrm{~mL})$ successively. The aqueous layers were mixed and extracted once with $\mathrm{Et}_{2} \mathrm{O}(30 \mathrm{~mL})$. The organic layers were combined, dried $\left(\mathrm{MgSO}_{4}\right)$, filtered, and concentrated in vacuo. The crude residue was purified by flash silica gel chromatography (0.2 to $1.0 \%$ EtOAc in hexanes) to afford $1.40 \mathrm{~g}(95 \%)$ of dithiane 9 as a colorless oil: $\mathrm{R}_{f}=0.33$ in $5 \%$ EtOAc/hexanes; $[\alpha]_{\mathrm{D}}^{20}+12.4\left(c 4.28, \mathrm{CH}_{2} \mathrm{Cl}_{2}\right)$; IR (neat) 3078, 2954, 2898, 1630, $1247 \mathrm{~cm}^{-1} ;{ }^{1} \mathrm{H}$ NMR (400 MHz, $\left.\mathrm{CDCl}_{3}\right) \delta 4.61(\mathrm{~s}, 1 \mathrm{H}), 4.56$ $(\mathrm{s}, 1 \mathrm{H}), 4.02(\mathrm{t}, J=6.4 \mathrm{~Hz}, 1 \mathrm{H}), 2.92-2.78(\mathrm{~m}, 4 \mathrm{H}), 2.15-2.06(\mathrm{~m}, 1 \mathrm{H}), 1.99-1.81(\mathrm{~m}$, $2 \mathrm{H}), 1.76-1.63(\mathrm{~m}, 3 \mathrm{H}), 1.54-1.44(\mathrm{~m}, 3 \mathrm{H}), 1.01(\mathrm{~d}, J=6.8 \mathrm{~Hz}, 3 \mathrm{H}), 0.02(\mathrm{~s}, 9 \mathrm{H}) ;{ }^{13} \mathrm{C}$ 
NMR $\left(101 \mathrm{MHz}, \mathrm{CDCl}_{3}\right) \delta 151.5,106.0,47.8,40.3,33.2,32.4,30.4,26.0,25.3$, 19.5, -1.2; HRMS m/e calcd for $\mathrm{C}_{14} \mathrm{H}_{28} \mathrm{~S}_{2} \mathrm{Si}(\mathrm{M})^{+}$288.1402, found 288.1416 .

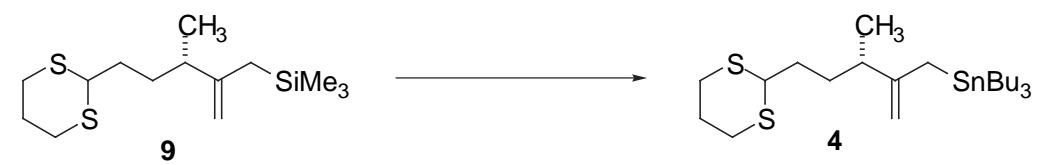

Allylbromide 10: Propylene oxide $(3.40 \mathrm{~mL}, 48.6 \mathrm{mmol})$, followed by recrystallized $\mathrm{N}$ bromosuccinimide $(4.29 \mathrm{~g}, 24.1 \mathrm{mmol})$ were added to a solution of allylsilane $9(1.39 \mathrm{~g}$, $4.82 \mathrm{mmol})$ in DMF: $\mathrm{CH}_{2} \mathrm{Cl}_{2}(40.0 \mathrm{~mL}: 30.0 \mathrm{~mL})$ at $-78^{\circ} \mathrm{C}$. The resultant suspension was stirred at $-78{ }^{\circ} \mathrm{C}$ for $6 \mathrm{~h}$. The cold $\left(-78^{\circ} \mathrm{C}\right)$ reaction mixture was quickly poured into a rapidly stirring mixture of saturated aqueous $\mathrm{NaHSO}_{3}(150 \mathrm{~mL})$ and $\mathrm{Et}_{2} \mathrm{O}(150 \mathrm{~mL})$ at 0 ${ }^{\circ} \mathrm{C}$. After stirring for $10 \mathrm{~min}$, the mixture was diluted with $\mathrm{Et}_{2} \mathrm{O}(100 \mathrm{~mL})$ and $\mathrm{H}_{2} \mathrm{O}(100$ $\mathrm{mL})$, and the phases were separated. The organic layer was washed with brine $(100 \mathrm{~mL})$, dried $\left(\mathrm{MgSO}_{4}\right)$, filtered, and concentrated in vacuo. The crude allylic bromide $\mathbf{1 0}$ was used without further purification.

Allylstannane 4: Freshly prepared lithium diisopropylamide $(10.1 \mathrm{~mL}$ of a $1.0 \mathrm{M}$ solution in THF, $10.1 \mathrm{mmol}$ ) was added dropwise to a solution of tributyltin hydride $(2.73 \mathrm{~mL}, 10.1 \mathrm{mmol})$ in $\mathrm{THF}(20.2 \mathrm{~mL})$ at $0{ }^{\circ} \mathrm{C}$. The resultant yellow solution was stirred for $30 \mathrm{~min}$ at $0{ }^{\circ} \mathrm{C}$ and added to a suspension of copper(I) bromide-dimethyl sulfide complex $(1.91 \mathrm{~g}, 9.16 \mathrm{mmol})$ in $\mathrm{THF}(30.0 \mathrm{~mL})$ at $-78{ }^{\circ} \mathrm{C}$. The dark brown mixture was stirred at $-78^{\circ} \mathrm{C}$ for $2 \mathrm{~h}$ and then a solution of crude allylic bromide 10 in THF $(\sim 10.0 \mathrm{~mL})$ was added via cannula. The reaction was warmed to $-40{ }^{\circ} \mathrm{C}$ over 30 min, quenched by addition of saturated aqueous $\mathrm{NH}_{4} \mathrm{Cl}(10.0 \mathrm{~mL})$ and warmed to room temperature. The mixture was diluted with $\mathrm{Et}_{2} \mathrm{O}(50.0 \mathrm{~mL})$ and then filtered through a plug of Celite ${ }^{\circledR}$. The filtrate was washed with saturated aqueous $\mathrm{NH}_{4} \mathrm{Cl}(50.0 \mathrm{~mL})$, brine $(50.0$ $\mathrm{mL})$, dried $\left(\mathrm{MgSO}_{4}\right)$, filtered, and concentrated in vacuo. Purification of the crude residue by flash chromatography $\left(\mathrm{SiO}_{2}\right.$ pre-equilibrated with $4 \% \mathrm{Et}_{3} \mathrm{~N} /$ hexanes, elution with hexanes) afforded $1.91 \mathrm{~g}(78 \%)$ of pure allyl stannane 4 as a colorless oil: $\mathrm{R}_{f}=0.47$ in $5 \%$ 
EtOAc/Hexanes; $[\alpha]_{\mathrm{D}}^{22}+0.81$ (c 0.80, hexanes); IR (neat) 3078, 2954, 2924, 1624, 1456, $1422 \mathrm{~cm}^{-1} ;{ }^{1} \mathrm{H}$ NMR $\left(400 \mathrm{MHz}, \mathrm{CDCl}_{3}\right) \delta 4.54-4.46(\mathrm{~m}, 2 \mathrm{H}), 4.01(\mathrm{t}, J=6.6 \mathrm{~Hz}, 1 \mathrm{H})$, 2.90-2.78 (m, 4H), 2.15-2.06 (m, 1H), 1.95-1.81 (m, 2H), 1.76-1.64 (m, 4H), 1.56$1.38(\mathrm{~m}, 8 \mathrm{H}), 1.35-1.24(\mathrm{~m}, 6 \mathrm{H}), 1.02(\mathrm{~d}, J=6.8 \mathrm{~Hz}, 3 \mathrm{H}), 0.91-0.82(\mathrm{~m}, 15 \mathrm{H}) ;{ }^{13} \mathrm{C}$ NMR $\left(101 \mathrm{MHz}, \mathrm{CDCl}_{3}\right) \delta 153.8,104.0,47.9,40.4,33.3,32.6,30.5,30.4,29.1$, 27.3, 26.1, 19.5, 17.5, 13.7, 9.5; HRMS $m / e$ calcd for $\mathrm{C}_{19} \mathrm{H}_{37} \mathrm{~S}_{2} \mathrm{Sn}(\mathrm{M}-\mathrm{Bu})^{+}$449.1359, found 449.1343 .

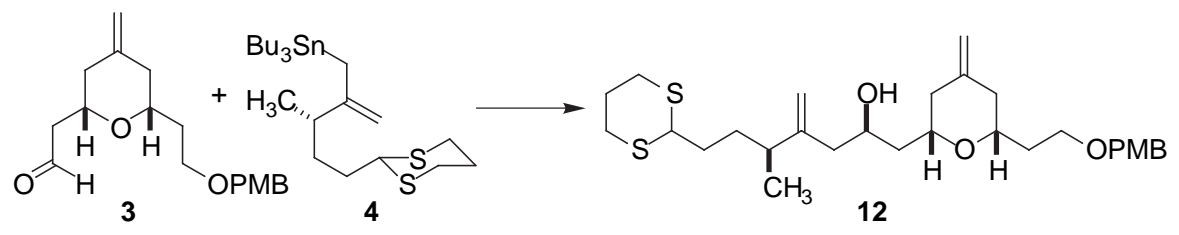

Alcohol 12: A $100 \mathrm{~mL}$ Schlenk flask was charged with $(R, R)$-1,2-bis-paratoluenesulfonyl-1,2-diphenylethane $(1.82 \mathrm{~g}, 3.49 \mathrm{mmol})$ and heated at $\sim 90{ }^{\circ} \mathrm{C}$ under vacuum $(0.2 \mathrm{~mm} \mathrm{Hg})$ for $12 \mathrm{~h}$. The white solid was cooled to room temperature and $\mathrm{CH}_{2} \mathrm{Cl}_{2}(20 \mathrm{~mL})$ was added under argon. The resultant solution was cooled to $0{ }^{\circ} \mathrm{C}$ and treated with fresh boron tribromide ( $3.49 \mathrm{~mL}$ of a $1.0 \mathrm{M}$ solution in $\mathrm{CH}_{2} \mathrm{Cl}_{2}, 3.49 \mathrm{mmol}$ ). The resulting orange solution was stirred at $0{ }^{\circ} \mathrm{C}$ for $10 \mathrm{~min}$, warmed to room temperature and stirred for $1 \mathrm{~h}$. The solvent and $\mathrm{HBr}$ were removed carefully under reduced pressure $(0.2 \mathrm{~mm} \mathrm{Hg})$. The resulting solid was dissolved in $\mathrm{CH}_{2} \mathrm{Cl}_{2}(15 \mathrm{~mL})$, stirred for $10 \mathrm{~min}$ and concentrated under high vacuum. The yellow solid was diluted again with $\mathrm{CH}_{2} \mathrm{Cl}_{2}$ (20 $\mathrm{mL})$ under argon, cooled to $0{ }^{\circ} \mathrm{C}$ and a solution of the allylstannane $4(1.90 \mathrm{~g}, 3.76 \mathrm{mmol})$ in $\mathrm{CH}_{2} \mathrm{Cl}_{2}(\sim 5 \mathrm{~mL})$ was added. The yellow solution was stirred for $16 \mathrm{~h}$ at room temperature. After this time the reaction was cooled to $-78{ }^{\circ} \mathrm{C}$ and a solution of aldehyde $\mathbf{3}$ (818 mg, $2.69 \mathrm{mmol})$ in $\mathrm{CH}_{2} \mathrm{Cl}_{2}(\sim 5 \mathrm{~mL})$ was added. The reaction mixture was stirred at $-78^{\circ} \mathrm{C}$ for $2 \mathrm{~h}$, and then quenched with $\mathrm{pH} 7$ buffer $(5 \mathrm{~mL})$. The mixture was allowed to warm to room temperature, and diluted with $\mathrm{CH}_{2} \mathrm{Cl}_{2}(30 \mathrm{~mL})$. The organic phase was washed with saturated aqueous $\mathrm{NaHCO}_{3}(40 \mathrm{~mL})$. The aqueous phase was extracted with 
$\mathrm{CH}_{2} \mathrm{Cl}_{2}(30 \mathrm{~mL})$. The combined organic phases were dried $\left(\mathrm{MgSO}_{4}\right)$, filtered, and concentrated in vacuo. The resulting solid was taken up with $\mathrm{Et}_{2} \mathrm{O}$ and filtered to recover the sparingly soluble bis-sulfonamide chiral auxiliary. The filtrate was concentrated in vacuo and the resulting residue purified by flash silica gel chromatography (10 to $15 \%$ EtOAc in hexanes) to yield $1.40 \mathrm{~g}(100 \%)$ of $\mathbf{1 2}$ as a $91: 9$ mixture of diastereomers, the major component of which was characterized as follows: $\mathrm{R}_{f}=0.32$ in $25 \%$ EtOAc/hexanes; $[\alpha]_{\mathrm{D}}^{20}+4.73\left(c 0.28, \mathrm{CH}_{2} \mathrm{Cl}_{2}\right)$; IR (neat) 3480, 3070, 2935, 1650, 1607, 1512, 1247 , $1095 \mathrm{~cm}^{-1} ;{ }^{1} \mathrm{H}$ NMR $\left(400 \mathrm{MHz}, \mathrm{CDCl}_{3}\right) \delta 7.25(\mathrm{~d}, J=8.6 \mathrm{~Hz}, 2 \mathrm{H}), 6.88(\mathrm{~d}, J=8.6 \mathrm{~Hz}$, 2H), $4.86(\mathrm{~s}, 1 \mathrm{H}), 4.83(\mathrm{~s}, 1 \mathrm{H}), 4.71$ (app s, 2H), 4.45-4.39 (m, 2H), 4.04-3.98 (m, 2H), 3.80 (s, 3H), 3.58-3.50 (m, 4H), 2.90-2.78 (m, 4H), 2.27-2.05 (m, 6H), 2.02-1.92 $(\mathrm{m}, 2 \mathrm{H}), 1.89-1.50(\mathrm{~m}, 10 \mathrm{H}), 1.03(\mathrm{~d}, J=6.8 \mathrm{~Hz}, 3 \mathrm{H}) ;{ }^{13} \mathrm{C} \mathrm{NMR}\left(101 \mathrm{MHz}, \mathrm{CDCl}_{3}\right) \delta$ $159.1,150.5,143.7,130.5,129.3,113.7,110.7,109.0,79.4,76.0,72.7,70.1,66.4$, 55.2, 47.8, 42.3, 42.1. 41.0, 40.5, 39.4, 36.2, 33.1, 32.3, 30.4, 26.0, 20.0; HRMS m/e calcd for $\mathrm{C}_{29} \mathrm{H}_{44} \mathrm{O}_{4} \mathrm{~S}_{2} \mathrm{Na}(\mathrm{M}+\mathrm{Na})+543.2591$, found 543.2581.

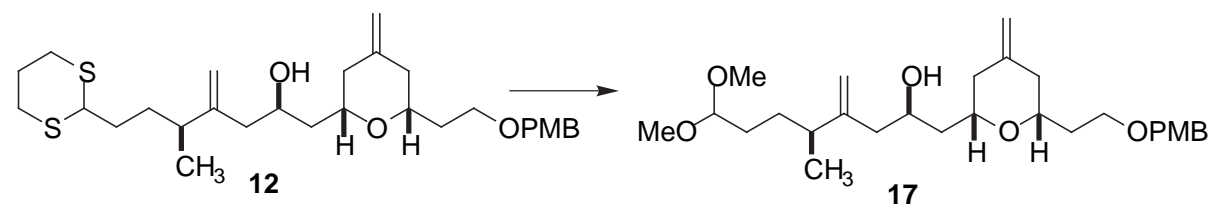

Dimethylacetal 17: Bis-trifluoroacetoxyiodobenzene (1.73 g, $4.02 \mathrm{mmol}$ ) was added in one portion to a stirred solution of dithiane $12(1.30 \mathrm{~g}, 2.50 \mathrm{mmol})$ in dry $\mathrm{MeOH}(13 \mathrm{~mL})$ at room temperature. After $5 \mathrm{~min}$, the reaction was quenched with saturated aqueous $\mathrm{NaHCO}_{3}(20 \mathrm{~mL})$, diluted with $\mathrm{H}_{2} \mathrm{O}(20 \mathrm{~mL})$ and $\mathrm{Et}_{2} \mathrm{O}(50 \mathrm{~mL})$. The layers were separated and the aqueous layer was extracted with $\mathrm{Et}_{2} \mathrm{O}(40 \mathrm{~mL})$. The combined organic layers were dried $\left(\mathrm{MgSO}_{4}\right)$, filtered and concentrated in vacuo. Purification by flash silica gel chromatography (20\% EtOAc in hexanes) afforded $920 \mathrm{mg}(77 \%)$ of alcohol 17: $\mathrm{R}_{f}=$ 0.38 in $50 \% \mathrm{EtOAc/hexanes;}[\alpha]_{\mathrm{D}}^{20}+3.28\left(c\right.$ 3.5, $\left.\mathrm{CH}_{2} \mathrm{Cl}_{2}\right)$; IR (neat) $3490,3072,2939$, 1652, 1613, 1513, 1248cm-1; ${ }^{1} \mathrm{H}$ NMR (400 MHz, $\left.\mathrm{CDCl}_{3}\right) \delta 7.26(\mathrm{~d}, J=8.2 \mathrm{~Hz}, 2 \mathrm{H})$, $6.88(\mathrm{~d}, J=8.2 \mathrm{~Hz}, 2 \mathrm{H}), 4.86(\mathrm{~s}, 1 \mathrm{H}), 4.83(\mathrm{~s}, 1 \mathrm{H}), 4.71(\operatorname{app~s}, 2 \mathrm{H}), 4.44$ (A of AB, $J$ 
$=11.6 \mathrm{~Hz}, 1 \mathrm{H}), 4.42(\mathrm{~B}$ of $\mathrm{AB}, J=11.6 \mathrm{~Hz}, 1 \mathrm{H}), 4.34(\mathrm{t}, J=5.6 \mathrm{~Hz}, 1 \mathrm{H}), 4.04-3.96$ (m, 1H), 3.80 (s, 3H), 3.73 (app s, 1H), 3.57-3.48 (m, 4H), 3.31 (s, 3H), $3.30(\mathrm{~s}, 3 \mathrm{H})$, 2.27-2.05 (m, 5H), 2.02-1.92 (m, 2H), 1.87-1.45 (m, 7H), 1.40-1.33 (m, 1H), $1.03(\mathrm{~d}$, $J=7.2 \mathrm{~Hz}, 3 \mathrm{H}) ;{ }^{13} \mathrm{C} \mathrm{NMR}\left(101 \mathrm{MHz}, \mathrm{CDCl}_{3}\right) \delta 159.1,150.9,143.7,130.5,129.3$, 113.7, 110.3, 109.0, 104.7, 79.4, 76.0, 72.7, 70.0, 66.4, 55.2, 52.7, 52.6, 42.3, 42.2, 41.0, 40.5, 39.5, 36.2, 30.2, 19.9; HRMS m/e calcd for $\mathrm{C}_{28} \mathrm{H}_{44} \mathrm{O}_{6}(\mathrm{M})^{+} 476.3138$, found 476.3150 .

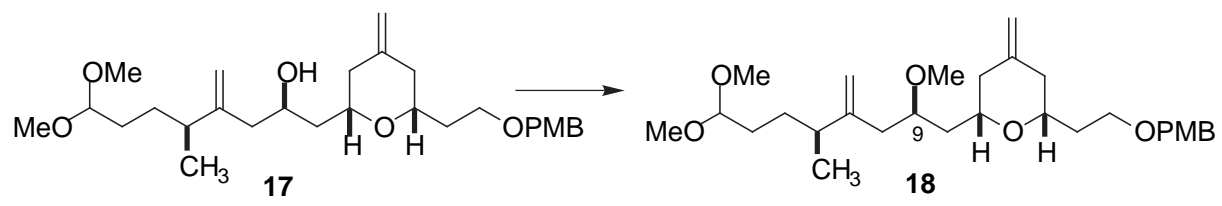

Methylether 18: To a solution of alcohol $17(1.17 \mathrm{~g}, 2.45 \mathrm{mmol})$ in $\mathrm{CH}_{2} \mathrm{Cl}_{2}(82 \mathrm{~mL})$ at $0{ }^{\circ} \mathrm{C}$ were added $4 \AA$ molecular sieves $(3.00 \mathrm{~g})$, Proton Sponge ${ }^{\circledR}(2.10 \mathrm{~g}, 9.80 \mathrm{mmol})$, and $\mathrm{Me}_{3} \mathrm{OBF}_{4}(1.09 \mathrm{~g}, 7.35 \mathrm{mmol})$ in that order. The reaction was allowed to warm gradually to room temperature, stirred $8 \mathrm{~h}$ and diluted with EtOAc $(50 \mathrm{~mL})$. The resulting suspension was filtered through a medium-fritted funnel, the filtrate was washed with $\mathrm{H}_{2} \mathrm{O}$ $(50 \mathrm{~mL})$, saturated aqueous $\mathrm{CuSO}_{4}(50 \mathrm{~mL})$, and the combined aqueous layers were extracted with EtOAc $(75 \mathrm{~mL})$. The combined organic layers were dried $\left(\mathrm{MgSO}_{4}\right)$, filtered and concentrated in vacuo. Purification by flash silica gel chromatography (12.5\% EtOAc in hexanes) afforded $1.07 \mathrm{~g}(88 \%)$ of pure methyl ether 18 (total yield 97\%; the diastereomers at $\mathrm{C}_{9}$ were separated at this point). Major product $\mathbf{1 8}$ was characterized as follows: $\mathrm{R}_{f}=0.42$ in $25 \%$ EtOAc/hexanes; $[\alpha]_{\mathrm{D}}^{24}-0.76$ (c 0.66, $\mathrm{CHCl}_{3}$ ); IR (neat) 2934, $1651,1609,1512,1249,1090 \mathrm{~cm}^{-1} ;{ }^{1} \mathrm{H}$ NMR $\left(400 \mathrm{MHz}, \mathrm{CDCl}_{3}\right) \delta 7.24(\mathrm{~d}, J=8.2 \mathrm{~Hz}$, $2 \mathrm{H}), 6.87(\mathrm{~d}, J=8.2 \mathrm{~Hz}, 2 \mathrm{H}), 4.82(\operatorname{app~s}, 2 \mathrm{H}), 4.71(\mathrm{~m}, 2 \mathrm{H}), 4.43(\mathrm{~A}$ of $\mathrm{AB}, J=11.5$ $\mathrm{Hz}, 1 \mathrm{H}), 4.41(\mathrm{~B}$ of $\mathrm{AB}, J=11.5 \mathrm{~Hz}, 1 \mathrm{H}), 4.33$ (t, $J=5.6 \mathrm{~Hz}, 1 \mathrm{H}), 3.79(\mathrm{~s}, 3 \mathrm{H}), 3.56$ (t, $J=6.4 \mathrm{~Hz}, 2 \mathrm{H}), 3.48(\mathrm{dddd}, J=6.0,6.0,6.0,6.0 \mathrm{~Hz}, 1 \mathrm{H}), 3.44-3.35(\mathrm{~m}, 2 \mathrm{H}), 3.31$ (s, 3H), $3.30(\mathrm{~s}, 6 \mathrm{H}), 2.29-2.08(\mathrm{~m}, 5 \mathrm{H}), 1.98-1.87(\mathrm{~m}, 2 \mathrm{H}), 1.87-1.70(\mathrm{~m}, 3 \mathrm{H}), 1.64-$ $1.42(\mathrm{~m}, 4 \mathrm{H}), 1.40-1.30(\mathrm{~m}, 1 \mathrm{H}), 1.01(\mathrm{~d}, J=6.8 \mathrm{~Hz}, 3 \mathrm{H}) ;{ }^{13} \mathrm{C} \mathrm{NMR}(101 \mathrm{MHz}$, 
$\left.\mathrm{CDCl}_{3}\right) \delta 159.1,150.9,144.6,130.6,129.2,113.7,110.2,108.5,104.6,76.8,75.4$, 75.4, 72.6, 66.6, 56.3, 55.2, 52.6, 52.5, 40.8, 40.8, 40.2, 39.4, 38.8, 36.4, 30.2, 19.9; HRMS m/e calcd for $\mathrm{C}_{29} \mathrm{H}_{46} \mathrm{O}_{6} \mathrm{Na}(\mathrm{M}+\mathrm{Na})^{+}$513.3192, found 513.3205.

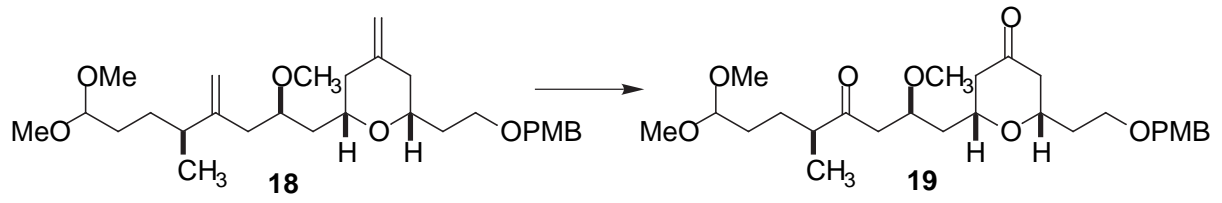

Diketone 19: 4-Methylmorpholine $N$-oxide ( $87 \mathrm{mg}, 0.74 \mathrm{mmol}$ ) was added to a solution of $18(0.12 \mathrm{~g}, 0.25 \mathrm{mmol})$ in 2:1 acetone:water $(7.0 \mathrm{~mL})$ at room temperature. The mixture was vigorously stirred, and a solution of osmium tetroxide (12 mg, $48 \mu \mathrm{mol})$ in tbutanol $(0.5 \mathrm{~mL})$ was added to it. After $2 \mathrm{~h}$ the mixture was quenched with saturated aqueous $\mathrm{Na}_{2} \mathrm{SO}_{3}(10 \mathrm{~mL})$, diluted with EtOAc $(15 \mathrm{~mL})$, the layers were separated, and the aqueous layer was extracted with EtOAc $(15 \mathrm{~mL})$. The combined organic layers were dried $\left(\mathrm{MgSO}_{4}\right)$, filtered and concentrated in vacuo. The crude residue was redissolved in THF: $\mathrm{H}_{2} \mathrm{O}(1: 1 \mathrm{v} / \mathrm{v}, 7.0 \mathrm{~mL})$, solid sodium periodate $(0.53 \mathrm{~g}, 2.5 \mathrm{mmol})$ was added and the suspension was stirred for $2 \mathrm{~h}$. The reaction was diluted with $\mathrm{H}_{2} \mathrm{O}(10 \mathrm{~mL})$, EtOAc $(15 \mathrm{~mL})$ and brine $(20 \mathrm{~mL})$. The layers were separated and the aqueous layer extracted with EtOAc $(25 \mathrm{~mL})$. The combined organic layers were dried $\left(\mathrm{MgSO}_{4}\right)$, filtered, and concentrated in vacuo. Purification by flash silica gel chromatography (using a gradient of $50 \%$ to $100 \%$ EtOAc in hexanes) afforded $107 \mathrm{mg}(88 \%)$ of diketone 19: $\mathrm{R}_{f}=0.70 \mathrm{in}$ $100 \%$ EtOAc; $[\alpha]_{\mathrm{D}}^{22}-7.76\left(c\right.$ 0.58, $\left.\mathrm{CH}_{2} \mathrm{Cl}_{2}\right)$; IR (neat) 2929, 1715, 1513, 1246, 1090 $\mathrm{cm}^{-1} ;{ }^{1} \mathrm{H} \mathrm{NMR}\left(400 \mathrm{MHz}, \mathrm{CDCl}_{3}\right) \delta 7.23(\mathrm{~d}, J=8.4 \mathrm{~Hz}, 2 \mathrm{H}), 6.87(\mathrm{~d}, J=8.4 \mathrm{~Hz}, 2 \mathrm{H})$, $4.42(\mathrm{~s}, 2 \mathrm{H}), 4.31(\mathrm{t}, J=5.6 \mathrm{~Hz}, 1 \mathrm{H}), 3.89-3.82(\mathrm{~m}, 1 \mathrm{H}), 3.80(\mathrm{~s}, 3 \mathrm{H}), 3.80-3.70(\mathrm{~m}$, $2 \mathrm{H}), 3.62-3.52(\mathrm{~m}, 2 \mathrm{H}), 3.30(\mathrm{~s}, 3 \mathrm{H}), 3.29(\mathrm{~s}, 3 \mathrm{H}), 3.27$ (s, 3H), $2.78(\mathrm{dd}, J=7.2$, $16.4 \mathrm{~Hz}, 1 \mathrm{H}), 2.54-2.47(\mathrm{~m}, 2 \mathrm{H}), 2.42-2.33(\mathrm{~m}, 2 \mathrm{H}), 2.29-2.19$ (m, 2H), 1.95-1.85 (m, $2 \mathrm{H}), 1.84-1.76(\mathrm{~m}, 1 \mathrm{H}), 1.73-1.62(\mathrm{~m}, 2 \mathrm{H}), 1.58-1.49(\mathrm{~m}, 2 \mathrm{H}), 1.42-1.31(\mathrm{~m}, 1 \mathrm{H})$, $1.08(\mathrm{~d}, J=7.2 \mathrm{~Hz}, 3 \mathrm{H}) ;{ }^{13} \mathrm{C}$ NMR $\left(101 \mathrm{MHz}, \mathrm{CDCl}_{3}\right) \delta 212.5,206.9,159.2,130.3$, $129.2,113.8,104.3,74.1,73.9,73.5,72.7,65.9,57.0,55.2,52.9,52.7,47.8,47.7$, 
$46.7,45.4,40.0,36.5,30.1,27.3,16.1$; HRMS $m / e$ calcd for $\mathrm{C}_{27} \mathrm{H}_{42} \mathrm{O}_{8} \mathrm{Na}(\mathrm{M}+\mathrm{Na})^{+}$ 517.2778, found 517.2790.

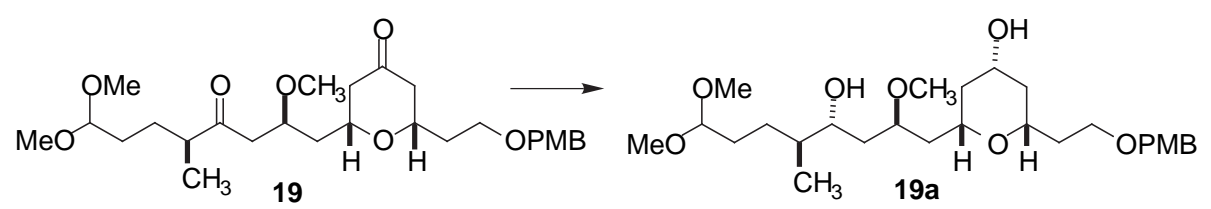

Diol 19a: Freshly prepared (+)-Terashima reagent ${ }^{16}\left(0.25 \mathrm{M}^{\text {in }} \mathrm{Et}_{2} \mathrm{O}, 13.4 \mathrm{~mL}, 3.35\right.$ mmol) was added dropwise to a solution of diketone 19 (275 $\mathrm{mg}, 0.556 \mathrm{mmol})$ in $^{2} \mathrm{Et}_{2} \mathrm{O}$ (7 $\mathrm{mL}$ ) at $-78{ }^{\circ} \mathrm{C}$. The mixture was stirred for $3 \mathrm{~h}$, quenched at $-78^{\circ} \mathrm{C}$ by careful addition of saturated aqueous $\mathrm{NaHCO}_{3}(5 \mathrm{~mL})$, warmed to room temperature, diluted with $\mathrm{H}_{2} \mathrm{O}$ (25 $\mathrm{mL})$, and then extracted with EtOAc $(2 \mathrm{X} 35 \mathrm{~mL})$. The organic layers were combined, dried $\left(\mathrm{MgSO}_{4}\right)$, concentrated in vacuo, and purification of the residue by flash silica gel chromatography (using a gradient of 1 to $4 \% \mathrm{MeOH}$ in $\mathrm{CH}_{2} \mathrm{Cl}_{2}$ ) to afford $275 \mathrm{mg}$ (99\%, $\mathrm{dr}>20: 1$ at $\mathrm{C}_{11}$, $\mathrm{dr} 8: 1$ at $\mathrm{C}_{5}$ ) of diol. The major isomer 19a was characterized as follows: $\mathrm{R}_{f}=0.13$ in $100 \%$ EtOAc; $[\alpha]_{\mathrm{D}}^{22}-1.43\left(c 0.63, \mathrm{CH}_{2} \mathrm{Cl}_{2}\right)$; IR (neat) 3435, 2932, 1612, $1511,1248,1120,1077,1031 \mathrm{~cm}^{-1} ;{ }^{1} \mathrm{H}$ NMR $\left(400 \mathrm{MHz}, \mathrm{CDCl}_{3}\right) \delta 7.24(\mathrm{~d}, J=8.4 \mathrm{~Hz}$, $2 \mathrm{H}), 6.87(\mathrm{~d}, J=8.4 \mathrm{~Hz}, 2 \mathrm{H}), 4.41(\mathrm{~s}, 2 \mathrm{H}), 4.33(\mathrm{t}, J=5.6 \mathrm{~Hz}, 1 \mathrm{H}), 3.80(\mathrm{~m}, 3 \mathrm{H})$, 3.80-3.75 (m, 1H), 3.69-3.60 (m, 2H), 3.60-3.49 (m, 2H), 3.49-3.41 (m, $1 \mathrm{H}), 3.41-$ $3.33(\mathrm{~m}, 1 \mathrm{H}), 3.33$ (s, 3H), 3.30 (s, 6H), 3.10 (br s, 1H), 2.02-1.88 (m, 3H), 1.84-1.64 $(\mathrm{m}, 5 \mathrm{H}), 1.62-1.46(\mathrm{~m}, 5 \mathrm{H}), 1.25-1.10(\mathrm{~m}, 3 \mathrm{H}), 0.86(\mathrm{~d}, J=6.8 \mathrm{~Hz}, 3 \mathrm{H}) ;{ }^{13} \mathrm{C}$ NMR $\left(101 \mathrm{MHz}, \mathrm{CDCl}_{3}\right) \delta 159.1,130.5,129.2,113.7,104.8,76.7,72.5,72.3,72.2,68.0$, 66.3, 56.6, 55.2, 52.7, 52.6, 41.5, 41.1, 38.8, 38.6, 36.0, 35.3, 30.1, 27.1, 15.1; HRMS m/e calcd for $\mathrm{C}_{27} \mathrm{H}_{46} \mathrm{O}_{8} \mathrm{Na}(\mathrm{M}+\mathrm{Na})^{+}$521.3091, found 521.3080. 

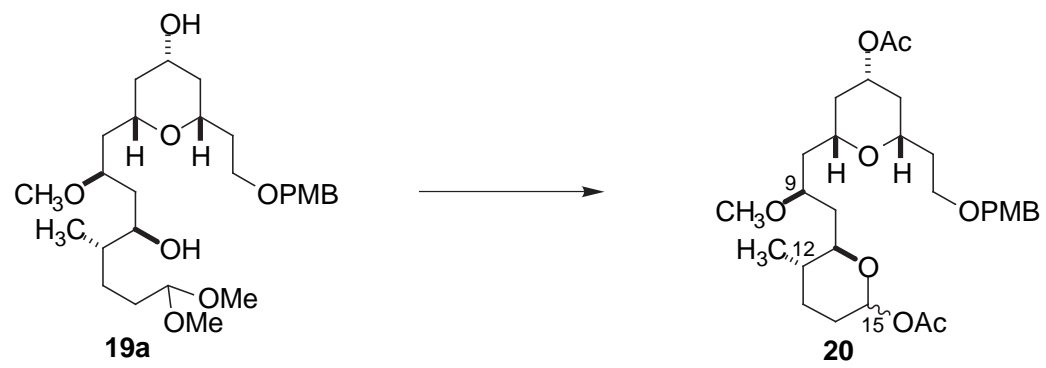

Diacetate 20: To a solution of diol 19a $(75 \mathrm{mg}, 0.15 \mathrm{mmol})$ in THF: $\mathrm{H}_{2} \mathrm{O}(3: 2 \mathrm{v} / \mathrm{v}, 5$ $\mathrm{mL}$ ) was added $85 \% \mathrm{H}_{3} \mathrm{PO}_{4}(0.5 \mathrm{~mL})$ at room temperature, and the mixture was stirred for $2 \mathrm{~h}$. The reaction was quenched carefully with dropwise addition of saturated aqueous $\mathrm{NaHCO}_{3}(5 \mathrm{~mL})$, extracted with $\mathrm{Et}_{2} \mathrm{O}(10 \mathrm{~mL})$, and then EtOAc $(15 \mathrm{~mL})$ was added. The organic layers were combined, dried $\left(\mathrm{MgSO}_{4}\right)$, filtered and concentrated in vacuo. The crude lactol was dissolved in $\mathrm{CH}_{2} \mathrm{Cl}_{2}(5.0 \mathrm{~mL})$ and then treated with pyridine $(243 \mu \mathrm{L}$, $3.00 \mathrm{mmol})$, acetic anhydride ( $283 \mu \mathrm{L}, 3.00 \mathrm{mmol})$, and DMAP (92 $\mathrm{mg}, 0.75 \mathrm{mmol})$. The reaction was stirred for $2 \mathrm{~h}$, diluted with $\mathrm{Et}_{2} \mathrm{O}(15 \mathrm{~mL})$, washed with saturated aqueous $\mathrm{NaHCO}_{3}(10 \mathrm{~mL})$ and brine $(10 \mathrm{~mL})$. The aqueous layers were extracted with $\mathrm{Et}_{2} \mathrm{O}(20$ $\mathrm{mL})$. The organic layers were combined, dried $\left(\mathrm{MgSO}_{4}\right)$, filtered and concentrated in vacuo. Purification via flash silica gel chromatography (25\% EtOAc in hexanes) afforded $68 \mathrm{mg}(84 \%)$ of diacetate $\mathbf{2 0}$ as a mixture of anomers. Key features for characterization of the mixture include: $[\alpha]_{\mathrm{D}}^{20}+20.7\left(c\right.$ 2.2, $\mathrm{CHCl}_{3}$ ); IR (neat) $2925,1739,1246 \mathrm{~cm}^{-1} ;{ }^{1} \mathrm{H}$ NMR $\left(400 \mathrm{MHz}, \mathrm{CDCl}_{3}\right) \delta 7.24(\mathrm{~d}, J=8.4 \mathrm{~Hz}, 2 \mathrm{H}), 6.87(\mathrm{~d}, J=8.4 \mathrm{~Hz}, 2 \mathrm{H})$, acetal methines at $6.08(\mathrm{~m})$ and $5.60(\mathrm{dd}, J=2.2,9.8 \mathrm{~Hz}), 4.87(\mathrm{dddd}, J=4.6,6.5,11.0,11.3$ $\mathrm{Hz}, 1 \mathrm{H}), 4.45$ (A of $\mathrm{AB}, J=11.6 \mathrm{~Hz}, 1 \mathrm{H}), 4.40(\mathrm{~B}$ of AB, $J=11.6 \mathrm{~Hz}, 1 \mathrm{H}), 3.79$ (s, $3 \mathrm{H}), 3.80-3.30(\mathrm{~m}, 6 \mathrm{H}), \mathrm{C}_{9}-\mathrm{OC} \underline{H}_{3}$ at $3.35(\mathrm{~s})$ and $3.29(\mathrm{~s}), \mathrm{C}_{15}-\mathrm{OCOC}_{3}$ at $2.07(\mathrm{~s})$ and $2.06(\mathrm{~s}), 2.02(\mathrm{~s}, 3 \mathrm{H}), 2.00-1.89(\mathrm{~m}, 2 \mathrm{H}), 1.88-1.66(\mathrm{~m}, 6 \mathrm{H}), 1.58-1.18(\mathrm{~m}, 7 \mathrm{H}), \mathrm{C}_{12^{-}}$ $\mathrm{C}_{3}$ at $0.85(\mathrm{~d}, J=6.4 \mathrm{~Hz})$ and $0.83(\mathrm{~d}, J=6.4 \mathrm{~Hz}) ; \mathrm{HRMS} m / e$ calcd for $\mathrm{C}_{29} \mathrm{H}_{44} \mathrm{O} 9 \mathrm{Na}$ $(\mathrm{M}+\mathrm{Na})^{+}$559.2883, found 559.2890. 


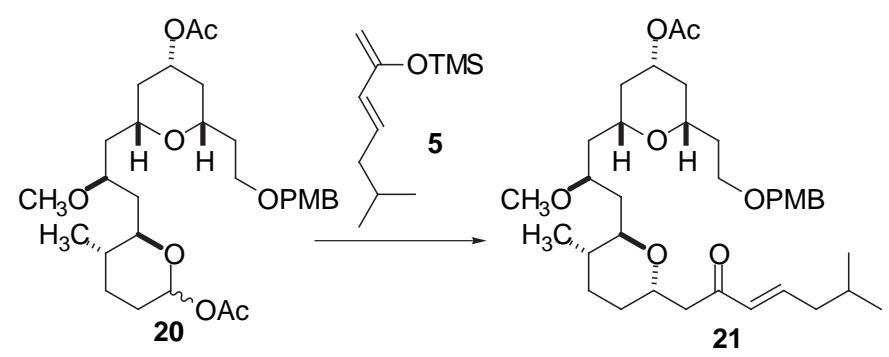

Enone 21: Fused zinc chloride ( $1 \mathrm{M}$ in $\mathrm{Et}_{2} \mathrm{O}, 842 \mu \mathrm{L}, 0.842 \mathrm{mmol}$ ) was added to a solution of diacetate $\mathbf{2 0}(113 \mathrm{mg}, 0.211 \mathrm{mmol})$ and silylenol ether 5 (209 $\mathrm{mg}, 1.06 \mathrm{mmol})$ in $\mathrm{CH}_{2} \mathrm{Cl}_{2}(4 \mathrm{~mL})$ at $-78{ }^{\circ} \mathrm{C}$. The reaction was allowed to warm gradually to room temperature, quenched with saturated aqueous $\mathrm{NaHCO}_{3}(10 \mathrm{~mL})$ and extracted with $\mathrm{Et}_{2} \mathrm{O}$ $(2 \mathrm{X} 30 \mathrm{~mL})$. The organic layers were combined, dried $\left(\mathrm{MgSO}_{4}\right)$, filtered and concentrated in vacuo. Purification via flash silica gel chromatography (25\% EtOAc in hexanes) afforded $108 \mathrm{mg}$ (85\%) of enone 21: $\mathrm{R}_{f}=0.41$ in 50\% EtOAc in hexanes; $[\alpha]_{\mathrm{D}}^{20}+14.0(c$ 1.1, $\mathrm{CH}_{2} \mathrm{Cl}_{2}$ ); IR (neat) $2951,2925,1735,1513,1245,1083,1029 \mathrm{~cm}^{-1} ;{ }^{1} \mathrm{H}$ NMR (400 $\left.\mathrm{MHz}, \mathrm{CDCl}_{3}\right) \delta 7.23(\mathrm{~d}, J=8.6 \mathrm{~Hz}, 2 \mathrm{H}), 6.86(\mathrm{~d}, J=8.6 \mathrm{~Hz}, 2 \mathrm{H}), 6.81(\mathrm{td}, J=15.8$, $8.1 \mathrm{~Hz}, 1 \mathrm{H}), 6.10(\mathrm{~d}, J=15.8 \mathrm{~Hz}, 1 \mathrm{H}), 4.88$ (dddd, $J=4.6,6.5,11.0,11.3 \mathrm{~Hz}, 1 \mathrm{H}$ ), 4.42 (A of AB, $J=11.5 \mathrm{~Hz}, 1 \mathrm{H}), 4.39$ (B of AB, $J=11.5 \mathrm{~Hz}, 1 \mathrm{H}), 4.33-4.27(\mathrm{~m}, 1 \mathrm{H})$, $3.79(\mathrm{~s}, 3 \mathrm{H}), 3.58-3.44(\mathrm{~m}, 6 \mathrm{H}), 3.28(\mathrm{~s}, 3 \mathrm{H}), 2.89(\mathrm{dd}, J=6.7,15.5 \mathrm{~Hz}, 1 \mathrm{H}), 2.72$ (dd, $J=6.8,15.5 \mathrm{~Hz}, 1 \mathrm{H}), 2.12-2.06(\mathrm{~m}, 2 \mathrm{H}), 2.03(\mathrm{~s}, 3 \mathrm{H}), 2.00-1.90(\mathrm{~m}, 2 \mathrm{H}), 1.86-$ $1.20(\mathrm{~m}, 14 \mathrm{H}), 0.94(\mathrm{~d}, J=6.4 \mathrm{~Hz}, 3 \mathrm{H}), 0.92(\mathrm{~d}, J=6.4 \mathrm{~Hz}, 6 \mathrm{H}) ;{ }^{13} \mathrm{C} \mathrm{NMR}(101 \mathrm{MHz}$, $\left.\mathrm{CDCl}_{3}\right) \delta 198.2,170.4,159.1,146.6,131.7,130.6,129.1,113.7,74.2,73.1,72.6$, $72.3,72.0,70.4,67.7,66.5,56.8,55.2,43.2,41.7,39.9,38.2,37.7,37.3,36.2,33.9$, 27.9, 27.6, 26.5, 22.3, 21.3, 18.3; HRMS m/e calcd for $\mathrm{C}_{35} \mathrm{H}_{54} \mathrm{O}_{8} \mathrm{Na}(\mathrm{M}+\mathrm{Na})^{+}$ 625.3717, found 625.3722. 


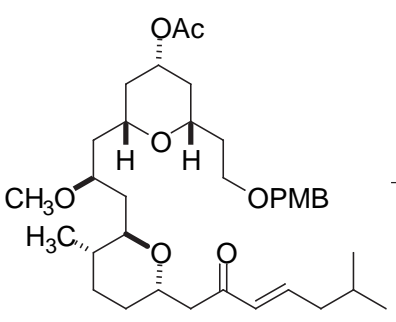

21

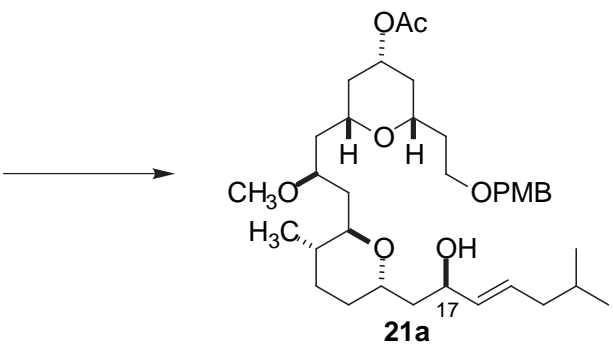

Allylic alcohol 21a: Borane•tetrahydrofuran complex (1 M in THF, $120 \mu \mathrm{L}, 0.120$ mmol) was added to a $-10{ }^{\circ} \mathrm{C}$ solution of $S$-methyl-oxazaborolidine (1 $\mathrm{M}$ in toluene, 60 $\mu \mathrm{L}, 60 \mu \mathrm{mol})$ in THF (1.0 mL) followed by a solution of enone $20(60 \mathrm{mg}, 0.10 \mathrm{~mol})$ in THF (1.0 mL). The reaction was allowed to warm to $5{ }^{\circ} \mathrm{C}$ over $1 \mathrm{~h}$ and then quenched with $\mathrm{H}_{2} \mathrm{O}(1 \mathrm{~mL})$. It was diluted with $\mathrm{H}_{2} \mathrm{O}(10 \mathrm{~mL})$ and extracted with $\mathrm{Et}_{2} \mathrm{O}(2 \mathrm{X} 20 \mathrm{~mL})$. The organic layers were combined, dried $\left(\mathrm{MgSO}_{4}\right)$, filtered and concentrated in vacuo. Purification via flash silica gel chromatography (25 to 40\% EtOAc in hexanes) afforded 48 mg $(80 \%)$ of product containing allylic alcohol 21a as the major component of a 5:1 mixture of diastereomers at $\mathrm{C}_{17}: \mathrm{R}_{f}=0.44$ in 50\% EtOAc in hexanes; IR (neat) 3450 , 2951, 2925, 1737, 1513, $1242 \mathrm{~cm}^{-1} ;{ }^{1} \mathrm{H}$ NMR (400 MHz, $\left.\mathrm{CDCl}_{3}\right) \delta 7.24(\mathrm{~d}, J=8.6 \mathrm{~Hz}$, 2H), $6.87(\mathrm{~d}, J=8.6 \mathrm{~Hz}, 2 \mathrm{H}), 5.64(\mathrm{td}, J=7.2,15.6 \mathrm{~Hz}, 1 \mathrm{H}), 5.48(\mathrm{dd}, J=6.4,15.6$ $\mathrm{Hz}, 1 \mathrm{H}), 4.88$ (dddd, $J=4.6,6.5,11.0,11.3 \mathrm{~Hz}, 1 \mathrm{H}), 4.43$ (A of $\mathrm{AB}, J=11.6 \mathrm{~Hz}$, $1 \mathrm{H}), 4.40(\mathrm{~B}$ of $\mathrm{AB}, J=11.6 \mathrm{~Hz}, 1 \mathrm{H}), 4.36-4.29(\mathrm{~m}, 1 \mathrm{H}), 4.00(\mathrm{~m}, 1 \mathrm{H}), 3.80(\mathrm{~s}, 3 \mathrm{H})$, 3.62-3.42 (m, 6H), $3.33(\mathrm{~s}, 3 \mathrm{H}), 2.85$ (d, $J=4.0 \mathrm{~Hz}, 1 \mathrm{H}), 2.03$ (s, 3H), 2.10-1.20 (m, $20 \mathrm{H}), 0.99(\mathrm{~d}, J=6.4 \mathrm{~Hz}, 3 \mathrm{H}), 0.88(\mathrm{~d}, J=6.8 \mathrm{~Hz}, 3 \mathrm{H}), 0.87(\mathrm{~d}, J=6.8 \mathrm{~Hz}, 3 \mathrm{H}) ;{ }^{13} \mathrm{C}$ NMR $\left(101 \mathrm{MHz}, \mathrm{CDCl}_{3}\right) \delta 170.5,159.1,134.2,130.4,129.5,129.3,113.7,74.6$, $73.1,72.5,72.3,72.1,70.4,69.0,67.3,66.2,56.6,55.2,41.6,40.3,39.6,37.7,37.6$, $37.2,36.1,33.4,28.2,27.7,26.2,22.3,22.2,21.3,18.4$; HRMS m/e calcd for $\mathrm{C}_{35} \mathrm{H}_{56} \mathrm{O}_{8} \mathrm{Na}(\mathrm{M}+\mathrm{Na})^{+}$627.3873, found 627.3858 . 


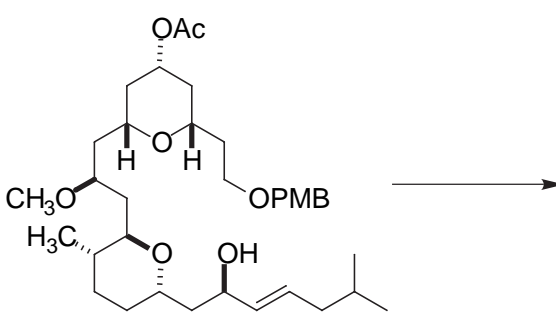

21a

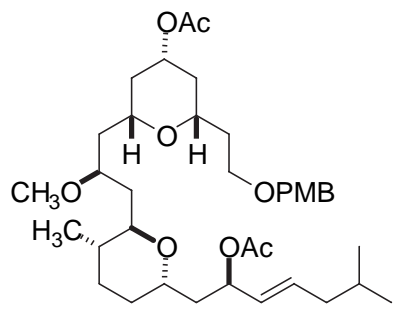

22

Diacetate 22: To a room temperature solution of allylic alcohol 21a (42 mg, $0.07 \mathrm{mmol}$ ) in $\mathrm{CH}_{2} \mathrm{Cl}_{2}(3.0 \mathrm{~mL})$ were added pyridine $(56 \mu \mathrm{L}, 0.70 \mathrm{mmol})$, acetic anhydride $(66 \mu \mathrm{L}$, $0.70 \mathrm{mmol}$ ) and DMAP (42 $\mathrm{mg}, 0.35 \mathrm{mmol})$. The mixture was stirred for $1 \mathrm{~h}$, then diluted with $\mathrm{NaHCO}_{3}(10 \mathrm{~mL})$ and $\mathrm{Et}_{2} \mathrm{O}(20 \mathrm{~mL})$. The layers were separated, the aqueous layer extracted with $\mathrm{Et}_{2} \mathrm{O}(20 \mathrm{~mL})$, the organic layers were combined, dried $\left(\mathrm{MgSO}_{4}\right)$, filtered and concentrated in vacuo. Purification via flash silica gel chromatography $(25 \%$ EtOAc in hexanes) afforded $42 \mathrm{mg}(94 \%)$ of diacetate 22 as the major component of a 5:1 mixture of diastereomers at $\mathrm{C}_{17}: \mathrm{R}_{f}=0.66$ in $50 \%$ EtOAc in hexanes; IR (neat) 2925, 2854, 1739, 1613, 1513, 1243, 1091, $1034 \mathrm{~cm}^{-1} ;{ }^{1} \mathrm{H}$ NMR $\left(400 \mathrm{MHz}, \mathrm{CDCl}_{3}\right) \delta 7.24(\mathrm{~d}, J=8.6 \mathrm{~Hz}$, 2H), $6.87(\mathrm{~d}, J=8.6 \mathrm{~Hz}, 2 \mathrm{H}), 5.68(\mathrm{td}, J=7.4,14.8 \mathrm{~Hz}, 1 \mathrm{H}), 5.43-5.27(\mathrm{~m}, 2 \mathrm{H}), 4.89$ (dddd, $J=4.6,6.5,11.0,11.3 \mathrm{~Hz}, 1 \mathrm{H}), 4.42(\mathrm{~A}$ of $\mathrm{AB}, J=11.6 \mathrm{~Hz}, 1 \mathrm{H}), 4.38$ (B of $\mathrm{AB}, J=11.6 \mathrm{~Hz}, 1 \mathrm{H}), 3.87-3.80(\mathrm{~m}, 1 \mathrm{H}), 3.80(\mathrm{~s}, 3 \mathrm{H}), 3.66-3.58(\mathrm{~m}, 1 \mathrm{H}), 3.58-3.41$ (m, 5H), $3.37(\mathrm{~s}, 3 \mathrm{H}), 2.03(\mathrm{~s}, 3 \mathrm{H}), 2.02(\mathrm{~s}, 3 \mathrm{H}), 2.00-1.20(\mathrm{~m}, 20 \mathrm{H}), 0.91(\mathrm{~d}, J=6.4$ $\mathrm{Hz}, 3 \mathrm{H}), 0.86(\mathrm{~d}, J=6.8 \mathrm{~Hz}, 6 \mathrm{H}) ;{ }^{13} \mathrm{C} \mathrm{NMR}\left(101 \mathrm{MHz}^{\mathrm{C}} \mathrm{CDCl}_{3}\right) \delta 170.5,170.1,159.1$, $132.7,130.6,129.7,129.2,113.7,73.7,72.6,72.3,71.8,71.7,71.5,70.4,67.4$, $66.6,56.6,55.2,41.5,39.2,38.6,37.9,37.3,36.6,36.2,34.7,28.2,28.0,26.9,22.2$, 22.2, 21.3, 18.4; HRMS m/e calcd for $\mathrm{C}_{37} \mathrm{H}_{58} \mathrm{O}_{9} \mathrm{Na}(\mathrm{M}+\mathrm{Na})^{+}$669.3979, found 627.3989. 


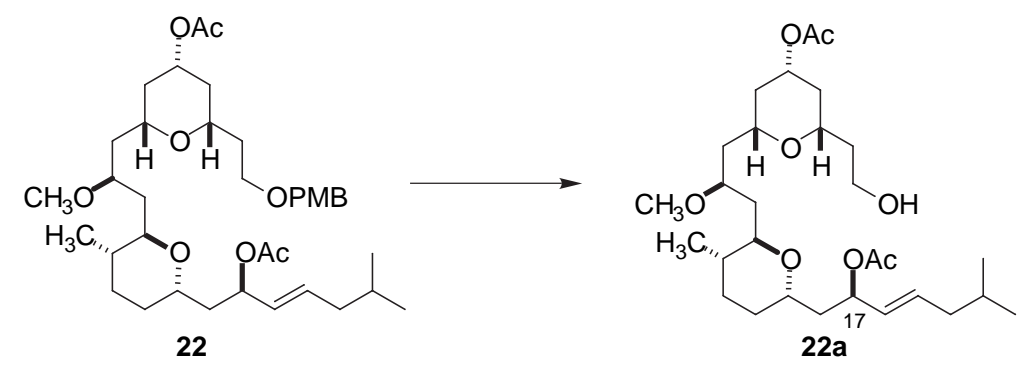

Alcohol 22a: To a room temperature solution of diacetate $22(41 \mathrm{mg}, 63 \mu \mathrm{mol})$ in $\mathrm{CH}_{2} \mathrm{Cl}_{2}(5.0 \mathrm{~mL})$ were added $\mathrm{pH} 7$ buffer $(2.0 \mathrm{~mL}),{ }^{t}$ butanol $(0.20 \mathrm{mmol})$ and DDQ (58 $\mathrm{mg}, 0.25 \mathrm{mmol}$ ) in that order. The dark green suspension was stirred for $45 \mathrm{~min}$ till it became dark red. The mixture was diluted with $\mathrm{Et}_{2} \mathrm{O}(10 \mathrm{~mL})$, washed with $\mathrm{NaHCO}_{3}(10$ $\mathrm{mL})$ and the aqueous layer was extracted with $\mathrm{Et}_{2} \mathrm{O}(10 \mathrm{~mL})$. The organic layers were combined, dried $\left(\mathrm{MgSO}_{4}\right)$, filtered and concentrated in vacuo. Purification via flash silica gel chromatography (33 to 50\% EtOAc in hexanes) afforded $32 \mathrm{mg}$ (96\%) of product containing alcohol 22a as the major component of a 5:1 mixture of diastereomers at $\mathrm{C}_{17}$ : $\mathrm{R}_{f}=0.36$ in $50 \%$ EtOAc in hexanes; IR (neat) 3455, 2952, 2921, 1741, 1240, 1088, 1030 $\mathrm{cm}^{-1} ;{ }^{1} \mathrm{H}$ NMR $\left(400 \mathrm{MHz}, \mathrm{CDCl}_{3}\right) \delta 5.70(\mathrm{td}, J=7.4,14.8 \mathrm{~Hz}, 1 \mathrm{H}), 5.44-5.28(\mathrm{~m}, 2 \mathrm{H})$, 4.90 (dddd, $J=4.7,6.3,11.0,11.3 \mathrm{~Hz}, 1 \mathrm{H}), 3.98-3.90(\mathrm{~m}, 1 \mathrm{H}), 3.87-3.77(\mathrm{~m}, 1 \mathrm{H})$, 3.76-3.67 (m, 1H), 3.66-3.58 (m, 2H), 3.49-3.40 (m, 2H), $3.40(\mathrm{~s}, 3 \mathrm{H}), 3.22$ (br s, $1 \mathrm{H}), 2.14-2.06(\mathrm{~m}, 1 \mathrm{H}), 2.03(\mathrm{~s}, 6 \mathrm{H}), 2.00-1.24(\mathrm{~m}, 19 \mathrm{H}), 0.91-0.84(\mathrm{~m}, 9 \mathrm{H}) ;{ }^{13} \mathrm{C}$ NMR $\left(101 \mathrm{MHz}, \mathrm{CDCl}_{3}\right) \delta 170.5,170.4,132.7,129.6,73.8,72.8,72.5,71.5,71.4$, $70.4,70.0,58.5,56.4,41.5,38.8,38.3,37.7,37.7,37.3,35.6,35.3,28.5,28.0,27.2$, 22.2, 22.2, 21.3, 18.2; HRMS $m / e$ calcd for $\mathrm{C}_{29} \mathrm{H}_{50} \mathrm{O}_{8} \mathrm{Na}(\mathrm{M}+\mathrm{Na})^{+}$549.3404, found 549.3412.

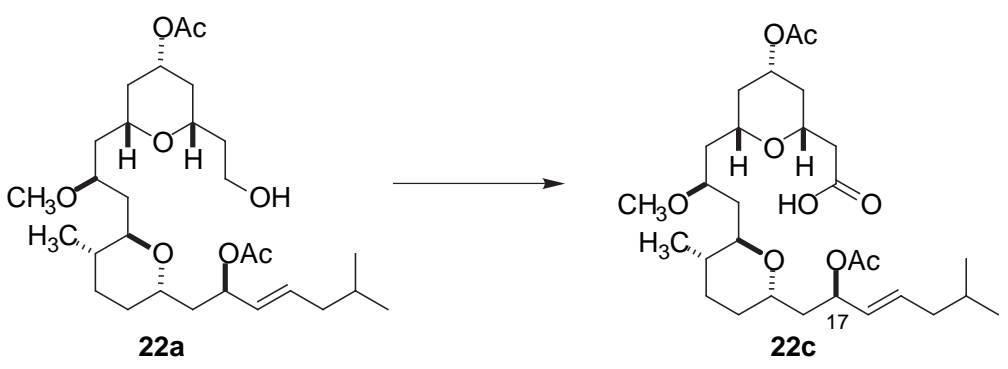


Aldehyde 22b: To a room temperature solution of alcohol 22a (32 $\mathrm{mg}, 61 \mu \mathrm{mol})$ in $\mathrm{CH}_{2} \mathrm{Cl}_{2}(2 \mathrm{~mL})$ was added solid $\mathrm{NaHCO}_{3}(51 \mathrm{mg}, 0.61 \mathrm{mmol})$ followed by Dess Martin periodinane $(128 \mathrm{mg}, 0.30 \mathrm{mmol})$. The reaction was stirred for $45 \mathrm{~min}$, quenched carefully with saturated aqueous $\mathrm{Na}_{2} \mathrm{~S}_{2} \mathrm{O}_{3}(5 \mathrm{~mL})$ and then extracted with $\mathrm{Et}_{2} \mathrm{O}(2 \mathrm{X} 20$ $\mathrm{mL})$. The organic layers were combined, dried $\left(\mathrm{MgSO}_{4}\right)$, filtered and concentrated in vacuo. Purification via flash silica gel chromatography (25\% EtOAc in hexanes) afforded $32 \mathrm{mg}(100 \%)$ of product aldehyde $\mathbf{2 2} \mathbf{b}$ as the major component of 5:1 mixture of diastereomers at $\mathrm{C}_{17}: \mathrm{R}_{f}=0.65$ in $50 \%$ EtOAc in hexanes; IR (neat) 2953, 2922, 2849, 1738, 1241, 1091, $1030 \mathrm{~cm}^{-1}$; ${ }^{1} \mathrm{H}$ NMR $\left(400 \mathrm{MHz}^{\mathrm{CDCl}} 3\right) \delta 9.77(\mathrm{~m}, 1 \mathrm{H}), 5.68(\mathrm{td}, J=$ 7.4, $14.8 \mathrm{~Hz}, 1 \mathrm{H}), 5.42-5.30(\mathrm{~m}, 2 \mathrm{H}), 4.93$ (dddd, $J=4.7,6.3,11.0,11.3 \mathrm{~Hz}, 1 \mathrm{H})$, 3.95-3.80 (m, 2H), 3.65-3.48 (m, 2H), 3.45-3.37 (m, 1H), $3.36(\mathrm{~s}, 3 \mathrm{H}), 2.60(\mathrm{ddd}, J=$ 2.8, 8.4, 16.4 Hz, 1H), 2.45 (ddd, $J=2.0,2.4,16.4 \mathrm{~Hz}, 1 \mathrm{H}), 2.04(\mathrm{~s}, 3 \mathrm{H}), 2.03$ (s, $3 \mathrm{H}), 2.06-1.96(\mathrm{~m}, 2 \mathrm{H}), 1.86-1.94(\mathrm{~m}, 2 \mathrm{H}), 1.78-1.20(\mathrm{~m}, 14 \mathrm{H}), 0.91(\mathrm{~d}, J=5.6 \mathrm{~Hz}$, 3H), $0.86(\mathrm{~d}, J=6.4 \mathrm{~Hz}, 6 \mathrm{H}) ;{ }^{13} \mathrm{C} \mathrm{NMR}\left(101 \mathrm{MHz}, \mathrm{CDCl}_{3}\right) \delta$ 201.0, 170.4, 170.1, $132.6,129.7,73.8,72.1,72.0,71.4,70.5,69.8,67.4,56.5,49.2,41.5,39.0,38.7$, $37.5,36.9,36.5,34.6,28.2,28.0,26.9,22.2,22.2,21.3,21.2,18.2$; HRMS m/e calcd for $\mathrm{C}_{29} \mathrm{H}_{48} \mathrm{O}{ }_{8} \mathrm{Na}(\mathrm{M}+\mathrm{Na})^{+}$547.3247, found 547.3249.

Acid 22c: A solution of aldehyde $22 b(30 \mathrm{mg}, 57 \mu \mathrm{mol})$ in $\mathrm{CH}_{3} \mathrm{CN}:{ }^{\mathrm{BuOH}}(1: 1 \mathrm{v} / \mathrm{v}, 3.0$ $\mathrm{mL})$ was cooled to $0{ }^{\circ} \mathrm{C}$ and 2 -methyl-2-butene $(300 \mu \mathrm{L})$ was added. A solution of $\mathrm{NaClO}_{4}(47 \mathrm{mg}, 0.52 \mathrm{mmol})$ and $\mathrm{NaH}_{2} \mathrm{PO}_{4}(69 \mathrm{mg}, 0.57 \mathrm{mmol})$ in $\mathrm{H}_{2} \mathrm{O}(0.5 \mathrm{~mL})$ was prepared and added to the reaction at $0{ }^{\circ} \mathrm{C}$. After 30 min the mixture was diluted with $\mathrm{Et}_{2} \mathrm{O}$ (5 mL), $\mathrm{H}_{2} \mathrm{O}(5 \mathrm{~mL})$, quenched with saturated aqueous $\mathrm{Na}_{2} \mathrm{~S}_{2} \mathrm{O}_{3}(5 \mathrm{~mL})$, warmed to room temperature, and extracted with $\mathrm{Et}_{2} \mathrm{O}(2 \mathrm{X} 15 \mathrm{~mL})$. The organic layers were combined, dried $\left(\mathrm{Na}_{2} \mathrm{SO}_{4}\right)$, filtered and concentrated in vacuo. The crude carboxylic acid 22c was used without purification in the next step. 


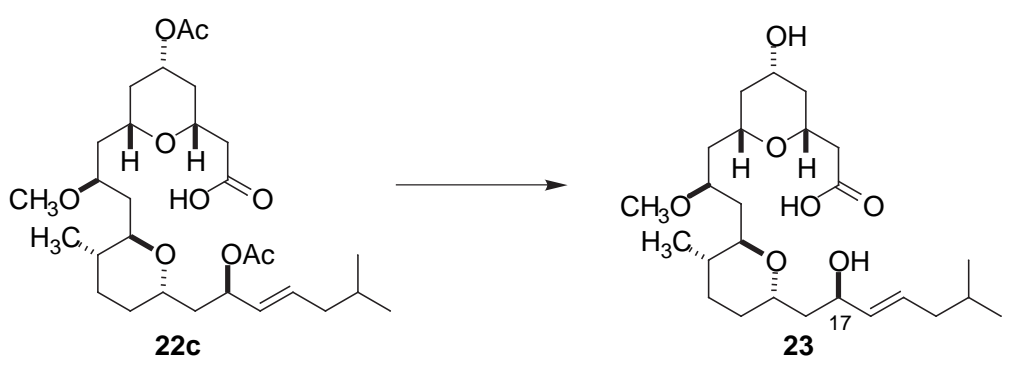

Seco-acid 23: The crude acid 22c $(\sim 57 \mu \mathrm{mol})$ was dissolved in anhydrous methanol (2 $\mathrm{mL})$. A suspension of sodium methoxide $(200 \mathrm{mg}, 3.70 \mathrm{mmol})$ in anhydrous $\mathrm{MeOH}(1.0$ $\mathrm{mL})$ was prepared, and $150 \mu \mathrm{L}(\sim 30 \mathrm{mg} \mathrm{NaOMe}, 0.56 \mathrm{mmol})$ of this stock solution was added to acid $22 \mathrm{c}$ at room temperature. After stirring for $1 \mathrm{~h}$, an additional portion of 150 $\mu \mathrm{l}$ of the $\mathrm{NaOMe}$ suspension in $\mathrm{MeOH}$ (10 eq.) was added and stirring for $4 \mathrm{~h}$ continued. After addition of more aliquot of $\mathrm{NaOMe}(30 \mu \mathrm{L}, 2$ eq.), followed by stirring for $1 \mathrm{~h}$, silica gel tlc inspection ( $10 \% \mathrm{MeOH}$ in $\mathrm{CH}_{2} \mathrm{Cl}_{2}$ ) revealed the total consumption of all starting material and intermediate monoacetylated material. The mixture was neutralized by addition of $2.5 \%$ aqueous $\mathrm{HCl}$ (total volume $1.4 \mathrm{~mL}$, added in $200-300 \mu \mathrm{L}$ portions), and then acidified to $\mathrm{pH} \sim 2$ by careful addition of more $2.5 \%$ aqueous $\mathrm{HCl}(5 \mathrm{X} 50 \mu \mathrm{L})$. The mixture was then diluted with $\mathrm{H}_{2} \mathrm{O}(3 \mathrm{~mL}), \mathrm{CH}_{2} \mathrm{Cl}_{2}(3 \mathrm{ml})$ and then extracted with $\mathrm{CH}_{2} \mathrm{Cl}_{2}(4 \mathrm{X} 10$ $\mathrm{mL})$. The organic layers were combined, dried $\left(\mathrm{Na}_{2} \mathrm{SO}_{4}\right)$, filtered and concentrated in vacuo. The crude residue was purified via flash silica gel chromatography (gradient solvent system: $2-15 \% \mathrm{MeOH}$ in $\mathrm{CH}_{2} \mathrm{Cl}_{2}$ ) to afford $20 \mathrm{mg}$ (80\%) of pure seco-acid 23 (total yield $98 \%$, the diastereomers at $\mathrm{C}_{17}$ were separated at this point). Seco-acid $\mathbf{2 3}$ was characterized as follows: $\mathrm{R}_{f}=0.32$ in $10 \% \mathrm{MeOH}$ in $\mathrm{CH}_{2} \mathrm{Cl}_{2} ;[\alpha]_{\mathrm{D}}^{25}+69.4$ (c 0.37, $\mathrm{CH}_{2} \mathrm{Cl}_{2}$ ); IR (neat) 3390, 2921, 1718, 1261, 1086, $1036 \mathrm{~cm}^{-1} ;{ }^{1} \mathrm{H}$ NMR (400 MHz, $\left.\mathrm{CDCl}_{3}\right) \delta 5.70(\mathrm{td}, J=7.6,15.2 \mathrm{~Hz}, 1 \mathrm{H}), 5.55(\mathrm{dd}, J=6.3,15.2 \mathrm{~Hz}, 1 \mathrm{H}), 4.36-4.30$ $(\mathrm{m}, 1 \mathrm{H}), 4.30-4.22(\mathrm{~m}, 1 \mathrm{H}), 3.90-3.81(\mathrm{~m}, 1 \mathrm{H}), 3.81-3.72(\mathrm{~m}, 1 \mathrm{H}), 3.68-3.62(\mathrm{~m}, 1 \mathrm{H})$, 3.46-3.39 (m, 1H), 3.34-3.27 (m, 1H), $3.32(\mathrm{~s}, 3 \mathrm{H}), 2.55(\mathrm{dd}, J=3.6,14.1 \mathrm{~Hz}, 1 \mathrm{H})$, $2.40(\mathrm{dd}, J=11.1,14.1 \mathrm{~Hz}, 1 \mathrm{H}), 2.38(\mathrm{~m}, 1 \mathrm{H}), 2.21-2.12(\mathrm{~m}, 1 \mathrm{H}), 2.05-1.18(\mathrm{~m}$, 18H), 0.90-0.84 (m, 9H); ${ }^{13} \mathrm{C}$ NMR (101 MHz, $\left.\mathrm{CDCl}_{3}\right) \delta 173.7,133.6,130.4,74.3$, 
$72.7,72.6,72.1,68.1,68.1,67.9,56.4,41.6,41.3,40.3,38.9,38.2,37.7,35.0,30.0$, 28.6, 28.2, 27.5, 22.3, 18.2; HRMS $m / e$ calcd for $\mathrm{C}_{25} \mathrm{H}_{44} \mathrm{O}_{7} \mathrm{Na}(\mathrm{M}+\mathrm{Na})^{+}$479.2985, found 479.2994 .

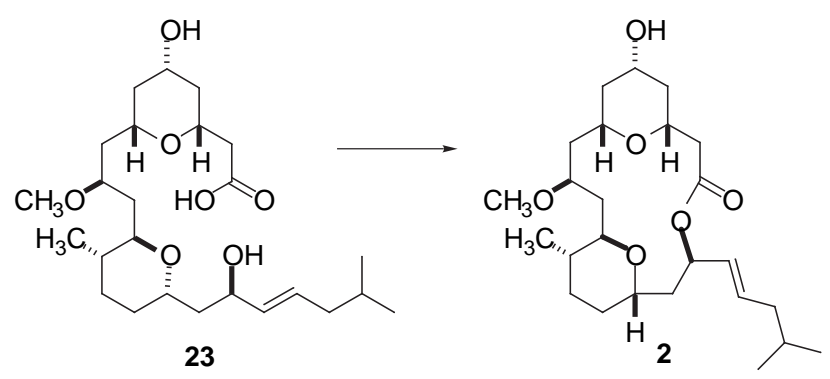

Macrolide 2: To a solution of pure seco-acid $23(6.2 \mathrm{mg}, 14 \mu \mathrm{mol}) \mathrm{THF}(1.0 \mathrm{~mL})$ at room temperature was added $\operatorname{Et}_{3} \mathrm{~N}(19 \mu \mathrm{L}, 0.14 \mathrm{mmol})$ followed by 2,4,6trichlorobenzoylchloride $(13 \mu \mathrm{L}, 0.08 \mathrm{mmol})$, and stirring was continued for $2 \mathrm{~h}$. The reaction was diluted with benzene $(4.0 \mathrm{~mL})$ and then added via syringe pump over $3 \mathrm{~h}$ to a refluxing solution of DMAP (20 mg, $0.16 \mathrm{mmol})$ in benzene $(27 \mathrm{~mL})$. After refluxing for an additional $1 \mathrm{~h}$, the reaction was cooled to room temperature, diluted with EtOAc (10 $\mathrm{mL}), \mathrm{H}_{2} \mathrm{O}(10 \mathrm{~mL})$ and washed with saturated aqueous $\mathrm{NaHCO}_{3}(10 \mathrm{~mL})$. The layers were separated, the aqueous layer was extracted with EtOAc $(10 \mathrm{~mL})$, and the organic layers were combined, dried $\left(\mathrm{Na}_{2} \mathrm{SO}_{4}\right)$, filtered and concentrated in vacuo. The crude residue was purified via flash silica gel chromatography (50\% EtOAc in hexanes) to afford $3.6 \mathrm{mg}(60 \%)$ of macrolide $2: \mathrm{R}_{f}=0.28$ in $33 \%$ hexanes in EtOAc; $[\alpha]_{\mathrm{D}}^{25}+45.0$ (c 1.0, EtOH); IR (neat) 3423, 2961, 2922, 2850, 1739, 1261, 1090, $1031 \mathrm{~cm}^{-1} ;{ }^{1} \mathrm{H}$ NMR (400 $\left.\mathrm{MHz}, \mathrm{C}_{5} \mathrm{D}_{5} \mathrm{~N}\right) \delta 6.57$ (br s, $\left.1 \mathrm{H}\right), 5.85-5.70(\mathrm{~m}, 2 \mathrm{H}), 5.58(\mathrm{dd}, J=7.0,15.4 \mathrm{~Hz}, 1 \mathrm{H})$, $4.09(\mathrm{~m}, 2 \mathrm{H}), 3.92-3.82(\mathrm{~m}, 2 \mathrm{H}), 3.80($ app t, 1H), 3.45 (app t, 1H), $3.36(\mathrm{~s}, 3 \mathrm{H}), 2.69$ $(\mathrm{dd}, J=3.7,13.1 \mathrm{~Hz}, 1 \mathrm{H}), 2.58-2.48(\mathrm{~m}, 2 \mathrm{H}), 2.24-2.11(\mathrm{~m}, 3 \mathrm{H}), 1.98-1.74(\mathrm{~m}, 5 \mathrm{H})$, 1.66-1.18 (m, 8H), $1.12(\mathrm{~d}, J=7.0 \mathrm{~Hz}, 3 \mathrm{H}), 1.10(\mathrm{~m}, 1 \mathrm{H}), 0.80(\mathrm{~d}, J=6.7 \mathrm{~Hz}, 3 \mathrm{H})$, $0.79(\mathrm{~d}, J=6.7 \mathrm{~Hz}, 3 \mathrm{H}) ;{ }^{13} \mathrm{C} \mathrm{NMR}\left(101 \mathrm{MHz} \mathrm{CDCl}_{3}\right) \delta 170.0,132.0,131.4,74.0$, 
$73.8,73.4,72.9,71.0,67.3,63.1,56.7,43.6,43.4,42.4,42.1,41.7,39.7,35.8,31.5$, $30.0,28.3,27.5,24.3,22.3,22.2,18.4$; HRMS m/e calcd for $\mathrm{C}_{25} \mathrm{H}_{42} \mathrm{O}_{6} \mathrm{Na}(\mathrm{M}+\mathrm{Na})^{+}$ 461.2879, found 461.2875. 